\title{
Beleefdheid in Afrikaans: 'n sosiolinguistiese perspektief
}

Barbara Bosch

Departement Afrikaans en Nederlands

Rhodes Universiteit

GRAHAMSTAD

\section{Abstract \\ Politeness in Afrikaans: a sociolinguistic perspective}

This article argues that because the phenomenon of linguistic politeness is embedded in a particular linguistic community, linguistic politeness should in the first instance be studied from sociolinguistic and pragmatic perspectives.

Using Afrikaans examples, different types of linguistic politeness are identified. The identified politeness types are discussed with special reference to conversational politeness, directives, complaints and honorifics. It is also argued that the specific choice of lexical items and 'in group' variants can be regarded as a form of linguistic politeness.

A feminist perspective on politeness clearly illustrates that linguistic politeness is an everchanging, dynamic concept which is closely linked to both interpersonal and societal associations which prevail at a specific point in time.

\section{Inleiding}

In die 'nuwe' Suid-Afrika bestaan daar elf amptelike tale en net soveel uiteenlopende kulture. Omdat kommunikasiepatrone aanmerklik tussen kulture $^{1}$ verskil, verstaan mense mekaar dikwels verkeerd omdat hulle

1 Die term kultuur moet in 'n so 'n wyd moontlike betekenis geïnterpreteer word: die kultuur van bepaalde subgroepe word hieronder ingesluit. 
aanvaar dat húl kommunikasiepatrone en -strategieë universeel geld. Met die oog op 'n vreedsame saambestaan van die verskillende taal- en kultuurgroepe is beleefde taalgebruik van belang.

Verskille in beleefdheid en pragmatiese 'foute' wat as gevolg hiervan kan ontstaan, kan by ' $n$ aansienlike persentasie taalgebruikers (Chick, 1989) 'n belangrike versperring in die proses van effektiewe interkulturele kommunikasie wees, omdat beleefdheid uit 'n bepaalde kulturele raamwerk geïnterpreteer word (Arndt \& Janney, 1992).

In die lig van hierdie gegewe is dit belangrik dat, hoewel die begrip beleefdheid as sinchronies-gedetermineerde talige gegewe voortdurend aan die verander is en dus moeilik vaspenbaar is, lede van 'n bepaalde taalgemeenskap bewus behoort te wees van die strategieë wat in daardie taalgemeenskap gebruik word om hoflik en beleefd te kommunikeer. Hiernaas behoort lede van 'n primêre taalgemeenskap (byvoorbeeld die primêre Afrikaanse taalgemeenskap ${ }^{2}$ ) ook kennis te dra van die beleefdheidsvoorwaardes wat binne die taalgemeenskappe van die ander tien amptelike tale geld.

Talle kommunikasieprobleme ontstaan in gevalle van interkulturele kommunikasie omrede die gespreksgenote probleme ondervind om veral gevoelens en houdings transkultureel akkuraat oor te dra (Amdt \& Janney, 1984). In 'n stedelike en plattelandse gemeenskap, in 'n Afrika- en Europese kultuur, kan twee totaal uiteenlopende interpretasies geheg word aan byvoorbeeld praat en stilswye, indirekte versoeke, bedekte opdragte, gespreksonderbreking, die afsluit van gesprekke, gesprekshandhawing, hoe die spreker hom-/haarself aan ander persone voorstel.

In die Afrika-situasie is dit byvoorbeeld vir die Afrikaan wat hom-/haarself in die dominante posisie bevind, beleefd om die meeste te praat, is dit onbeleefd om die beste voet voor te sit en bestaan daar 'n opmerklike tydsverloop in die opvolging van praatbeurte in die geval van sprekers van inheemse Afrikatale en Engels (Gough, 1992). Afrikane "appear to emphasize social distance and power in their interaction ... a system which imposes an asymmetry on relationships in the talk exchange enhancing the status and power relationships of the interactants" (Gough, 1992:4). As

2 Volgens Du Plessis (1989:473) al die sprekers wat Afrikaans as moedertaal of ook as eerste taal gebruik. 
gevolg hiervan aanvaar Afrikane direktheid in taalgebruik slegs tussen dominante en gedomineerde spreker; indien ' $n$ gedomineerde met ' $n$ persoon in 'n hoër posisie kommunikeer, is indirektheid die aanvaarbare linguistiese norm (Gough, 1992:4).

Met die oog op doeltreffende kommunikasie is dit dus nodig dat sprekers kennis dra van die beleefdheidsisteme wat in die onderskeie tale geld: indien die beleefdheidsisteme van die Engelssprekende en Afrikataalspreker byvoorbeeld in botsing sou kom, kan dit tot misverstande en ondoeltreffende kommunikasie aanleiding gee.

\section{Linguistiese beleefdheid}

Deurdat taal in 'n sosiale gemeenskap ingebed is, is ook die reëls wat taalgedrag bepaal, ingebed in die taalgemeenskap waarbinne dit funksioneer (Goody, 1978:3). As gevolg hiervan verkry taal strategiese waarde in die interaksieproses: in 'n hiërargies-geordende gemeenskap het linguistiese beleefdheid die handhawing van ' $n$ balans in interaksie ten doel (Held, 1992:143). 'n Beleefde taaluiting "... mediates between the individual and the social" (Werkhofer, 1992:156); gevolglik is samewerking en beleefdheid in baie gevalle interaktief. Uit 'n pragmatiese konteks benader is kennis van die "verbal routines" (Coulmas, 1981:1) wat in 'n bepaalde spraakgemeenskap geld dus belangrik vir die handhawing van beleefde kommunikasie.

In die struktureringsproses van sosiale interaksie is beleefde taalgedrag sosiaal-gedetermineer, en werk dit terselfdertyd mee aan die struktureringsproses van sosiale interaksie (Werkhofer, 1992:156). In dié verband kan gepraat word van die mag van beleefdheid: die beleefdheidsbeginsel motiveer en bepaal die keuse van taalvorme (byvoorbeeld die gebruik van modale partikels, aanspreekvorme en die keuse van leksikonitems) (Werkhofer, 1992:190).

Vir die doel van die bespreking word linguistiese beleefdheid beskou as 'n stel beperkinge wat op 'n bepaalde stadium ten opsigte van verbale gedrag geld en wat terselfdertyd verband hou met statusbewuste gedrag en die handhawing van menswaardigheid (Held, 1992:137).

Hoewel linguistiese beleefdheid aan bepaalde taalvorme gekoppel kan word, is beleefde taaluitings (weens die sosiale aard van linguistiese 
beleefdheid) die gevolg van ' $n$ interaksie tussen linguistiese en situasionele faktore (Held, 1992).

\subsection{Positiewe linguistiese beleefdheid}

Brown en Levinson (1978:75) identifiseer positiewe linguistiese beleefdheid as daardie vorm van linguistiese beleefdheid wat toenaderingsgeoriënteerd is. Die spreker gee baie duidelik aan die hoorder te kenne dat hulle aan dieselfde groep behoort en op dieselfde statusvlak verkeer. Aan die hoorder word oorgedra dat daar respek vir sy sosiale posisie bestaan. Vergelyk die volgende voorbeeld:

- Julle is seker dood van die honger. Kom ons gaan maak iets om te eet.

- Dis 'n pragtige rok. Waar het jy dit gekry?

Positiewe linguistiese beleefdheid kan oorgedra word deur verskillende strategieë, byvoorbeeld die keuse van aanspreekvorme, in group-taal en terminologie, die keuse van gespreksonderwerpe en deur grappe wat gekies word om in 'n bepaalde situasie vertel te word (Brown \& Levinson, 1978).

Die beleefdheidskonsep in literêre tekste kan uit 'n resepsie-teoretiese ${ }^{3}$ literêre perspektief bestudeer word om vas te stel in hoe 'n mate positiewe linguistiese beleefdheid in 'n teks deur bepaalde strategieë (byvoorbeeld die keuse van inhoudsmateriaal en die taalgebruik) gehandhaaf of ondermyn word. Sodanige tekstuele benadering belig enersyds die sosiaal-bepaalde determinante onderliggend aan beleefdheid en illustreer terselfdertyd die historisiteitsaard van beleefdheid (Sell, 1992). 'n Bepaalde teks wat met publikasie beskou is as synde onbeleefd, kan later as beleefd herwaardeer word omdat die konformiteite en waardesisteme wat tydens publikasie gegeld het, nie noodwendig op 'n latere stadium mutatis mutandis geld nie".

3 Die begrip resepsieteorie word in die wydste sin van die woord gebruik vir alle rigtings in die literatuurstudie wat gemoeid is met die leser se resepsie van literêre werke (Cloete, 1992:427).

4 Die polemiek rondom André P. Brink se Kennis van die aand, die eerste direkte opposisioneel politieke roman in Afrikaans (Coetzee, 1990:42), wat in 1974 verban en later ontban word, is ' $n$ voorbeeld hiervan. 


\subsection{Negatiewe linguistiese beleefdheid}

Negatiewe linguistiese beleefdheid (wat veral ten opsigte van versoeke gebruik word), is uitsluitlik daarop gerig om nie die hoorder se status aan te tas nie en ondersteuning aan die hoorder te bied (Held, 1992:142). Die spreker gee baie duidelik te kenne dat daar nie inbreuk gemaak word op die hoorder se keusevryhede nie en daar word aan die hoorder oorgedra dat die keuse pertinent by hom/haar gelaat word.

Die ruimte vir hierdie 'uitkomkans' ten opsigte van die keuse kan geskep word deurdat die spreker eksplisiet met die hoorder se situasie identifiseer (Ek weet jy is baie besig in die onderstaande voorbeeld). Hierdie identifisering word onder andere bewerkstellig deur die gebruik van bepaalde linguistiese elemente wat op onbeslistheid dui (sou en nie ... nie in die onderstaande voorbeeld):

- Ek weet jy is baie besig, maar sou dit nie vir jou moontlik wees om vir my te help nie?

Negatiewe linguistiese beleefdheid word volgens Brown en Levinson (1978) veral deur konvensionele indirektheid aan die hoorder oorgedra:

- Kan ek jou vra om die venster toe te maak?

- Gee jy om om die venster toe te maak?

- Dis koud hier in die klas.

\section{Beleefdheid in Afrikaans}

Uit 'n pragmatiese konteks benader, is kennis van die "verbal routines" (Coulmas, 1981:1) wat in 'n bepaalde spraakgemeenskap geld, belangrik vir die handhawing van beleefde kommunikasie.

\subsection{Beleefdheid in gesprekvoering}

Fraser en Nolan (1981:96) stel dat linguistiese beleefdheid die gevolg is van 'n gesprekskontrak wat tussen die deelnemers gesluit word in 'n poging om konflikvrye sosio-kommunikatiewe verbale interaksie te verseker.

Die samewerkingsbeginsel (Grice, 1975), wat as voorwaarde vir doeltreffende gespreksvoering geld, stel die een gespreksgenoot in staat om te 
kommunikeer op grond van die aanname dat die ander gespreksgenoot meewerk. Deur byvoorbeeld aan die aangesprokene op ' $n$ beleefde wyse 'n positiewe beeld oor hom-/haarself te sein, word sy/haar samewerking in die kommunikasieproses verkry. Vergelyk die volgende voorbeeld:

- Dis 'n heerlike nagereg! Kan ek die resep kry?

Indien die samewerkingsbeginsel nie in gesprekke gehandhaaf word nie, word die beleefdheidsbeginsel (Levinson, 1983) wat in kommunikasie geld, verbreek.

Die verhouding tussen die spreker en die hoorder word veral gevestig en gemanifesteer in die aanspreekvorme, name en in group-variante wat gebruik word.

\subsubsection{Taktiese strategieë}

Verskillende soorte taktiese strategieë kan in die kommunikasiesituasie ingespan word ten einde in die kommunikasieproses samewerking tussen spreker en hoorder te verkry.

\subsubsection{Beleefdheidsformules as taktiese strategie}

Soos in ander tale (Ferguson, 1989), word ook in Afrikaans bepaalde beleefdheidsformules in gespreksvoering gebruik - beleefdheidsformules wat daarop gerig is om die aangesprokene se samewerking te verkry (Brown \& Levinson, 1978:130). Vergelyk die volgende voorbeelde:

- Goeie môre/middag/naand.

- Gesondheid! (as iemand nies).

- Baie dankie/ nie te danke.

- Geseënde Kersfees.

Hierdie uitdrukkings is in taalgemeenskappe in 'n hoë mate geformulariseer en sosiaal-gedetermineer (Ferguson, 1989:34): totsiens kan nie as gespreksinleier gebruik word nie en goeie middag het geen paradigmatiese vervangingsmoontlikhede nie (vergelyk *slegte middag). Om in bepaalde omstandighede nie groetvorme te gebruik nie of onaanvaarbare groetvorme

3 Die begrip name word nie net vir eiename gebruik nie, maar ook vir soortname. 
of reaksies te gebruik, kan as onbeleefde taalgedrag beskou word.

\subsubsection{Indirekte taalhandelinge as taktiese strategie}

Beleefdheid is in baie gevalle die verklaring vir die gebruik van indirekte taalhandelinge. In die geval van indirekte taalhandelinge moet die spreker die situasie/konteks so noukeurig moontlik in die lig van sy/haar intensie beoordeel, want die indirekte taalhandelinge word nie deur die vorm of deur 'n performatief ondubbelsinnig gemerk nie (Van Jaarsveld, 1987:8).

Conradie (1987) dui aan dat die beginsel onderliggend aan die pogings van sprekers om illokusies (byvoorbeeld ' $n$ bevel of 'n versoek) indirekter uit te druk, direk te make het met die minimalisering van gesag (of verantwoordelikheid). Indirekte taalhandelinge kan dus as 'n taktvolle manier beskou word om konfliksituasies te ontlont. Indirektheid verhoog die beleefdheidsgraad van 'n uiting: dit bied onder andere 'n uitvoeringskeuse aan die hoorder (Leech, 1983:107-110).

Konvensionele indirektheid kon egter in bepaalde kontekste so geïnstitusionaliseer geraak het dat dit aan die hoorder nie eintlik meer 'n keuse laat nie. Vergelyk die volgende voorbeelde:

- Internasionale regulasies verbied rook op passasiersvliegtuie. (By implikasie: $E k$ sê dat $j y$ nie mag rook nie.)

- Dit is nie moontlik dat met die Minister gepraat kan word nie. ( $E k$ sê met ander woorde dat $j y$ nie met die Minister mag praat nie.)

In die bogenoemde strategieë word van onpersoonlike stelwyses (naamlik onpersoonlike subjekte en die passiewe vorm) gebruik gemaak.

Die indirekte taalhandelinge word 'n bepaalde kode (Brown \& Levinson, 1978:87) en die akkurate interpretasie van die omgewing determineer die behoefte aan taalvorme wat beleefdheid oordra: in dié verband speel sosiale afstand, mag en kultuurgebonde gebruike 'n deurslaggewende rol.

\subsubsection{Aanspreekvorme as taktiese strategie}

Op grond van 'n pragmatiese beskouing van kommunikasie verteenwoordig die aanspreekvorm die taalmatige enkodering van die spreker se waarneming en evaluering van die aangesprokene in die totale situasie. 
Die aanspreekvorm kan gevolglik beskou word as die gekodifiseerde aanduiding van die verhouding tussen die spreker en die aangesprokene (Jenkinson, 1987:69). Die keuse van aanspreekvorme word in baie gevalle deur die beleefdheidsbeginsel gemotiveer en bepaal (Werkhofer, 1992:190).

Aanspreekvorme kan deur die spreker gebruik word om 'n gemeenskaplike groepsverband (byvoorbeeld ten opsigte van gemeenskaplike behoeftes, doelstellings en waardes) aan die hoorder te sein (Brown \& Levinson, 1978).

In Afrikaans word $u$ veral gebruik om hoflikheidswaardes oor te dra (Odendal, 1976:11):

- Meneer die Vise-Kanselier, sal $u$ asseblief voortgaan?

Hoewel die gebruik van $j y$ nie heeltemal onmoontlik is nie, skep dit binne die formele gespreksregister tog die indruk van onhoflikheid:

- Meneer die Vise-Kanselier, sal $j y$ asseblief voortgaan?

In die volgende situasie bestaan daar 'n duidelik aantoonbare magskloof tussen die spreker en die hoorder omdat die aanspreekvorm meneertjie 'n baie sterk pejoratiewe waarde het:

- Kyk meneertjie, dit is beter om hierdie sakie nie verder te voer nie.

\subsubsection{Leksikonitems as taktiese strategie}

Indien die spreker probeer om sover as moontlik hoflik te wees, dan sal hy/sy sover moontlik 'neutrale' (polities-korrekte/polities-versagtende) woordkeuses maak in die strewe om aanstoot te vermy en dus linguisties beleefd op te tree.

Omdat name van veral openbare plekke en instansies noodwendig nie polities-neutraal kan wees nie en dus as 'n vorm van gemerkte taal beskou kan word, kan name en die gebruik daarvan in die 'nuwe Suid-Afrika' as vorme van beleefde of onbeleefde taalgebruik geïnterpreteer word. Die herrie wat die premier van die Vrystaat-provinsie, mnr. Patrick Lekota hom (teen die einde van 1994) op die hals gehaal het met sy uitspraak dat 
Bloemfontein voortaan Mangaung (plek van die luiperd) genoem behoort te word, is ' $n$ bewys hiervan.

Stellenbosch het B.J. Vorster-, H.F. Verwoerd-, J.C. Smuts- en D.F. Malan-geboue. Suid-Afrika se Departement van Gevangenisse se naam is onlangs verander na Korrektiewe Dienste. 'n Geldverkwister is bloot 'n negatiewe spaarder en iemand wat nog onsensitief genoeg is om van moffies te praat pleks van gays ly aan 'n erge graad van homofobie. Voor 27 April 1994 het niemand in linkse kringe van die Regering gepraat nie, maar van die Regime. Polities-korrekte taalgebruik kan as 'n vorm van beleefdheid beskou word.

Binne die Suid-Afrikaanse konteks is 'n ondersoek na die gebruik van raspejoratiewe ${ }^{6}$ ook insiggewend ten opsigte van die veranderende sosiaalgedetermineerde waardes wat op 'n bepaalde tydstip in die gemeenskap gegeld het. Sodoende kan geillustreer word hoe linguistiese beleefdheid deur die gebruik van eufemistiese leksikonitems gereflekteer kan word.

Calitz (1980) stel dat benoeminge vir etniese groepe in Suid-Afrika, wat eens heel gebruiklik en vry van ekspressiewe waardes was, in die tweede helfte van die twintigste eeu weens 'n betekenisverandering en/of betekenisverslegting as gevolg van die ideologiese beroeringe van ons tyd taboewoorde geword het. Eufemismes word gebruik om die terme wat aanstoot gee, te vervang: die gebruik van naturel, bantoe en swartman/ swarte was oorspronklik eufemistiese plaasvervangers vir kaffer, maar het baie gou weer ' $n$ negatiewe en afkeurenswaardige gevoelswaarde ontwikkel.

House en Kasper (1981:166-168) stel dat versagtende leksikonitems as gradeerbare merkers van beleefdheid kan optree. In Afrikaans kan bepaalde merkers gebruik word om die effek wat die spreker se uiting op die hoorder het te versag.

In die onderstaande voorbeeld word die leksikonitems effens, 'n bietjie, ' oomblikkie as versagters gebruik:

- Dokter is effens/'n bietjie laat. Wag asseblief 'n oomblik(kie).

6 Onder die term raspejoratiewe word verstaan etnies-gefundeerde terme wat in Suid-Afrika vir mense van kleur aanstootlik is (Van Heerden, 1989:79). 


\subsubsection{In group-variante as taktiese strategie}

Die gebruik van ' $n$ tipe in group-taalvorm kan op beleefdheid aan die kant van die spreker dui en daar word outomaties 'n solidariteitsgevoel tussen spreker en hoorder bewerkstellig. Deurdat gespreksreëls nagekom en die hoorder geakkommodeer word, kan die gebruik van in group-variante onder bepaalde omstandighede as ' $n$ vorm van beleefde taalgebruik beskou word.

Binne die Afrikaanse taalgemeenskap sou die doelbewuste gebruik van byvoorbeeld 'bejaarde taal' deur gespreksgenote wat tot verskillende generasies behoort, hierdie solidariteit kon bewerkstellig. Volgens Coupland et al. (1991) word bejaarde taal onder andere gekenmerk deur beperkte keuses ten opsigte van gespreksonderwerpe (byvoorbeeld die verlede, kinders, persoonlike gesondheid) en 'n geneigdheid van bejaardes om tydsperspektiewe by hul gesprekke te betrek (byvoorbeeld presiese numeriese merkers word gebruik om vertellings uit die verlede te plaas).

\subsection{Beleefde direktiewe}

Beleefdheid speel ' $n$ belangrike rol in die keuse van die linguistiese vorm waarin die spreker kies om 'n spesifieke direktief aan 'n bepaalde hoorder te rig en in die proses die hoorder te manipuleer (Terblanche, 1987:129). Beleefdheid is by 'direktiewe' (bevele, versoeke) dié belangrikste dryfveer. Dit kan egter ook 'n dryfveer wees by die gee van toestemming vir 'n sensitiewe spreker (Conradie, 1987:107).

\subsubsection{Die 'verhouding' tussen die spreker en aangesprokene}

Die 'verhouding' (hiërargies of andersins) waarin die spreker en aangesprokene tot mekaar staan, het noodwendig implikasies vir die rig van direktiewe, vergelyk:

- Matrone teenoor verpleegster: Bring die medisyne!

- Dosent teenoor student: Dis warm in die klaskamer.

- Man teenoor vrou (afhangende van die statusverhouding binne die spesifieke huwelik):

- Maak vir my koffie!

- Koffie asseblief. 
- Het jy nie lus om vir my koffie te maak nie?

- Koffie sal nou lekker smaak.

Die volgende voorbeeld illustreer verskillende aspekte:

- $\quad$ Ek is jammer om te pla, maar ek is in die moeilikheid en het gewonder of jy my nie dalk sou kon help nie.

In hierdie voorbeeldsin is dit duidelik dat die spreker verleë en nederig is (Ek is jammer om te pla), en komplekse semantiese (ek het gewonder, dalk sou kon help) en bepaalde sintaktiese strukture (stapeling van konjunksie deur neweskikking ${ }^{7}$ gebruik om hom-/haarself uit te druk.

\subsubsection{Sintaktiese strategië}

Sekere sintaktiese vorme is daarop gerig om die perlokusie-effek (die reaksie wat die versoek op die aangesprokene sal hê) te versag. Deur die gebruik van bepaalde sinsvorme, aanspreekvorme en sekere modaliteitsaanduiders, word verseker dat die hoorder nie deur die versoek in 'n posisie geplaas word waarin dit vir hom/haar onmoontlik is om nie aan die versoek te voldoen nie:

- Ek het gewonder (verlede tydsvorm) of dit nie moontlik sou wees (modaliteitsmerker) om ...

- Sou dit nie 'n goeie idee wees om vanaand in die Spur te gaan eet nie? (modaliteitsmerker, vraagvorm)

- Die boek asseblief! (modale partikel)

Om solidariteit met die hoorder te illustreer, kan die spreker 'n optrede aan die hand doen waaraan hy/sy self ook gaan deelneem. In Afrikaans is dit veral die hortatief-konstruksie (met die werkwoorde laat/kom in kombinasie met die onderwerp ons) wat in hierdie konteks gebruik word (Ponelis, 1979:390). Vergelyk die volgende twee voorbeelde met die daaropvolgende vraagstelling:

- Laat ons gou die blomme gaan wegbring.

7 Die herhaalde gebruik van neweskikkers as koördineerders bewerkstellig ' $n$ los aaneenskakeling van gedagtes om 'n sentrale tema (hier die rig van 'n versoek). In beplande skryftaal sou voorkeur aan die gebruik van 'n onderskikkende voegwoord verleen word (Bosch, 1994:23). 
- Kom ons gaan gou die blomme wegbring.

- En wat sal gebeur as die wêreld môre vergaan?

In die vraagstelling oortree die gebruiker egter die hoflikheidsgespreksvoorwaardes (Van Jaarsveld, 1987:115), want onder normale omstandighede onderbreek die spreker nie die gesprek om die hoorder in staat te stel om op die vraagappél te reageer nie omdat hy/sy self 'n stelling wil maak.

Die hoorder kan egter ook onhoflik reageer deur 'n belaglike reaksie, byvoorbeeld:

- Dan dra ons almal blou hoedjies.

\section{Beleefde klagtes}

Bepaalde strategieë kan in Afrikaans gebruik word om beleefd te kla.

* Die spreker kan aanduiders gebruik wat ondubbelsinnig aan die hoorder dui dat die spreker persoonlik verantwoordelikheid vir sy stelling aanvaar:

- Ek dink/glo/meen/veronderstel dat dit 'n ongeluk was.

* Die spreker kan vooraf 'n waarskuwing aan die aangesprokene rig:

- Piet, ek wil jou nie ontstel nie/ek waardeer wat jy gedoen het/dit verveel jou miskien, maar ...

* Die spreker kan probeer verseker dat die aangesprokene nie die aangebode inligting as 'n bedreiging sal ervaar nie:

- Dit pla mý nie, maar jou kind is besig om die hond te verf.

\section{Beleefdheid in en van literêre tekste}

Deur te kyk na bepaalde beleefdheidstrategieë in 'n bepaalde teks, is dit moontlik om inligting wat in die teks ingebed was, maar wat nie voorheen 'raakgesien' is nie, na die oppervlak te bring. Indien daar deur byvoorbeeld 'feministiese oë' na 'n teks gekyk word en in die tradisie van die Franse feminisme gefokus word op taal en die wyse waarop die sosiale maatskappy deur taal gekonstrueer is, is dit moontlik om die gender- en 
patriargale magskomponente (wat vroeër dan nie raakgesien is nie), waar te neem.

Sell (1992:116) beweer dat, omrede beleefdheid nie op voorspelbare maniere funksioneer nie, die effektiewe gebruik van hoflikheid in 'n literêre teks juis op die genialiteit van die skrywer dui.

\subsection{Beleefdheid in literêre tekste}

\subsubsection{Ons is nie almal so nie (Goosen, 1990)}

'n Versigtige (met oop oë as't ware) lees van die teks maak dit dan moontlik om waar te neem wat die teks nie mag sê nie, nie kan sê nie of nie wil sê nie. In Ons is nie almal so nie word 'n feministiese lees van die teks ondersteun deur die beleefde taalgebruik in die teks; wat die teks nie durf uitspel nie, is dat beleefdheid magsgekoppel is.

\subsubsection{Aanspreekvorme en verwysvorme}

In Ons is nie almal so nie is die gebruik van aanspreekvorme en verwysingsvorme 'n duidelike kode vir die aanduiding van die sosiale verwantskap tussen die figure in die teks. Hierdie linguistiese merkers kan sowel die ouderdom van die aangesprokene as dié van die spreker, sosiale strukture en sielkundige samestelling van die betrokkenes verklap (Mehrotra, 1981:121).

Die aanspreekvorme (Aapsticks, my kind, Gertietjie, my girlie) wat deur die volwassenes teenoor die kind (Gertie) gebruik word, dui op 'n duidelike hiërargiese verhoudingspatroon. Wanneer Piet (die vader) haar Klimmeid noem, lê daar in die aanspreekvorm enersyds toegeneentheid en vertroeteling opgesluit, maar daarnaas ook die negatiewe Suid-Afrikaanse waarde van meid.

Nêrens in die teks is daar onsekerheid oor die aanspreekvorme van die vrouefigure nie. Die rede hiervoor is waarskynlik die situering van die vrou in tradisionele rolle. Hieroor sê Key (1974:47) "when women continue to function in traditional roles there is no confusion in which title to use or how to address them". 


\subsubsection{Opdragte en voorstelle}

Die verskillende maniere waarop die manlike en vroulike figure in die teks opdragte gee en voorstelle maak, dui op 'n hoflikheidverskil in die taalgebruik. Vrouetaal word gekenmerk deur 'n uiters hoflike kommunikasiepatroon, want "women must uphold social conventions" (Lakoff, 1975:55).

In Ons is nie almal so nie is daar 'n merkbare verskil in die manier waarop Doris (die ma) en Piet (die pa) aan Gertie (die kind) opdragte gee. Doris rig beleefde versoeke, vergelyk:

- "Gertie", sê my ma, "gaan haal gou vir ons die lang spieël in Ma-hulle se kamer dan sit $j y$ soet op die vloer ...". (p. 14)

In teenstelling met die bogenoemde taalgebruikspatrone staan Piet, wat Gertie in elk geval byna nooit direk aanspreek nie, se outoritêre opdragte:

- "Sit soos 'n meisiekind!" (p. 37)

- "Gaan was jou gesig!" (p. 37)

Die taalvorme wat deur Piet geimplementeer word vir die gee van opdragte ondersteun die tradisioneel hiërargies ondergeskikte verhouding wat tussen pa en dogter bestaan.

\subsection{Beleefdheid van literêre tekste}

\subsubsection{Kennis van die aand (Brink, 1973)}

Die beleefdheidsgraad van 'n literêre teks kan bepaal word deur onder andere te kyk na die keuse van inhoudsmateriaal en taalgebruik. Sell (1992:117) beweer dat skrywers seleksiebeleefdheid en aanbiedingsbeleefdheid in tekste implementeer. ${ }^{8}$

André P. Brink se Kennis van die aand, die eerste direkte opposisioneel politieke roman in Afrikaans (Coetzee, 1990:42) word in 1974 verbied:

8 Sell (1992:117) formuleer die onderskeid soos volg: "Selectional politeness ... embraces features ... from the underlying interaction between writer and readers, where the choice of some types of subject matter constitutes a face-threatening act and ... some types of languages ... mitigate such an act ...". Aanbiedingsbeleefdheid handhaaf die samewerkingsbeginsel tussen gespreksgenote ten alle koste. 
Kennis se verhaal word deur 'n 'gekleurde' sentrale karakter (Josef Malan) vertel en handel onder andere oor 'n seksuele verhouding oor die kleurgrens.

Die skrywer oortree waarskynlik doelbewus die parameters van die seleksiebeleefdheid wat in 1974 gegeld het, waarskynlik in die strewe na waargenome eerlikheid oor die Suid-Afrikaanse gegewe van die tyd. Brink is "... committed to exploring and exploiting the South African political situation specifically in order to comment on it in a way which directly attempts to change it" (Meintjes, 1994:8). Die oortreding van die grense van aanbiedingsbeleefdheid (die diskoersdeiksis, scenario's wat geskets word, die oortreding van groepsgrense en kommunikatiewe dinamiek (Sell, 1992:117)) word inderwaarheid die formele (lees "taalkundige") ekwivalent van die moderne materiaal wat aangebied word.

\subsubsection{Raspejoratiewe}

Daar is in die dekade van tagtig binne Afrikaanse literêre kringe 'n heftige debat gevoer oor die wenslikheid al dan nie om literêre tekste van raspejoratiewe te suiwer (Van Heerden, 1986 en 1989; Ferreira, 1986), omdat "... baie lesers in Suid-Afrika raspejoratiewe toenemend as die linguistiese stut van arbeids-, besits-, en gesagsverhoudings in ons gemeenskap (ervaar)" (Van Heerden, 1989:79). Hierdie 'gesuiwerde' tekste was dan daarop gerig om bepaalde tekste meer aanvaarbaar te maak vir die huidige geslag lesers (Van Heerden, 1989:80).

In die vasstelling van wat die beleefdheid van 'n bepaalde literêre teks inhou, moet egter ook in gedagte gehou word dat wat met 'n eerste oogopslag as rassisties mag voorkom, nie noodwendig ooreenstem met wat die outeur/spreker wil sê nie.

Die studie van beleefdheid in en van literêre tekste dui duidelik aan dat menslike gedrag en die waardes wat aan morele terme geheg word gedurigdeur aan die verander is.

\section{6. 'n Feministiese perspektief op beleefdheid}

Die sosiaal-hiërargiese beskouing van beleefdheid aanvaar noodwendig die daarstelling van sosiale standaarde en die implikasie dat sosiale sanksies 
geïmplementeer sal word indien hierdie standaarde nie gehandhaaf word nie.

Volgens Althusser (1971) word 'n bepaalde ideologie deur taal oorgedra, dit bevestig die mag van die heersende groep en word ondersteun deur instellings soos skole, kerke, die reg, kultuur, en selfs taal. Indien beleefdheid ideologies-gedetermineer is, word die ideologie dus ook deur taal ondersteun: daar word erken dat (binne 'n bepaalde ideologie) daar dinge is wat nie mag, nie kan, nie wil gesê word nie (Macherey, 1978).

Watts et al. (1992:5) argumenteer inderdaad dat taalstandaardiseringsprosesse (ten opsigte van styl, grammatikale, leksikale en fonologiese standaarde) wat as vertrekpunt in beleefde taalgebruik geneem word, in wese ' $n$ magspel is en dat hierdie normering deur geïnstitusionaliseerde instansies (byvoorbeeld Taalakademies en Taalkommissies) gereguleer word: beleefdheid is dus in werklikheid "... a set of behaviour patterns preprogrammed as social norms by those possessing power" (Watts et al., 1992:5).

Tannen (1992) beweer dat mans en vroue die wêreld, en gevolglik ook kommunikasie binne die wêreld, verskillend beleef. In die kommunikasiewêreld van die vrou is verbondenheid en intimiteit die sleutel; in die kommunikasiewêreld van die man is status en onafhanklikheid die sleutel (Tannen, 1992:19). Indien doeltreffende kommunikasie beteken dat die teenstrydige behoeftes van intimiteit (ons is dieselfde en deel ' $n$ gemeenskaplike band) en onafhanklikheid/status (ons is verskillend) op 'n doeltreffende wyse gebalanseer behoort te word, sal dit bepaalde implikasies hê vir die gebruik en interpretasie van beleefde taalgebruik.

Afhangende van die perspektief waaruit gekommunikeer word (gevolglik dus die metaboodskap van status en verbondenheid), kan verskillende grade van hoflikheid wat in taalhandelinge gebruik word, 'n subtiele aanduiding van respek wees (Tannen, 1992:130).

Tannen (1992:234-5) beweer egter ook dat beleefdheid en grade van beleefde taalgebruik gender-gekoppel geïnterpreteer kan word. Uit die manlike perspektief sein dit 'onderdanigheid' en uit die vroulike perspektief 'gevoeligheid'. 
Beleefde taalgebruik sou egter ook as kommunikasie uit 'n 'swakkere' gespreksposisie geïnterpreteer kon word (Brown \& Levinson, 1978:256); hoofsaaklik omdat die spreker nie gesien word as iemand wat 'n dominante posisie in die gesprekshiërargie beklee nie.

\section{Beleefdheid - quo vadis?}

Die ondersoeker se indruk is dat Suid-Afrikaners voor April 1994 hoofsaaklik intrakultureel gekommunikeer het, maar dat die behoefte aan interkulturele kommunikasie nou 'n gegewe is waarvandaan nie wegbeweeg kan word nie.

In 'n multitalige multikulturele gemeenskap, soos wat die 'nuwe SuidAfrika' inderdaad is, het talle nuwe situasies en die vloeibaarheid van grense tot gevolg dat mense binne verskuifde paradigmas funksioneer. Beleefdheid is ' $n$ begrip wat in 'n bepaalde kultuur of groep ten nouste saamhang met die interpersoonlike verhoudings en sosiale konvensies waarop die lede van die groep ooreengekom het op die tydstip dat kommunikasie plaasvind. Gevolglik is beleefdheid 'n dinamiese begrip "... always open to adaptation and change in any group, in any age, and, indeed, at any moment of time" (Watts et al., 1992:11).

In Suid-Afrika verkeer taalgebruik in ' $n$ veranderende fase wat aanpassings van alle betrokkenes verg. Hopelik is dit duidelik dat die laaste woord beslis nog nie oor beleefdheid binne die Suid-Afrikaanse taalgebied gespreek is nie: daar behoort nou binne die Suid-Afrikaanse konteks spesifiek oor beleefdheid in sy (haar?) nuwe etniese baadjie en oor kultuurgebonde vorme van beleefheid navorsing gedoen te word - uit ' $n$ historiese sowel as sinchroniese perspektief.

\section{Ten slotte}

Linguistiese beleefdheid is uiteraard 'n verwikkelde kwessie. Hoewel bepaalde linguistiese patroonmatighede aangetoon kan word, word linguistiese beleefdheid in 'n hoë mate sosiaal en kultureel bepaal.

Interkulturele beleefdheid kan beslis nie bereik word deur beleefdheidformules bloot van die een taal in die ander te vertaal nie (Janney \& Arndt, 1992). Deur bepaalde strategieë (byvoorbeeld deur doelbewuste akkom- 
modasie van die hoorder, die vermyding van die ontstaan van 'n negatiewe kommunikasieraamwerk ${ }^{9}$ ) in te span, is dit egter wel moontlik om transkultureel beleefd te kommunikeer (Janney \& Arndt, 1992:41).

In hierdie artikel is probeer om beleefde taalgebruik in Afrikaans te verklaar deur onder andere te fokus op die sosiolinguistiese verskeidenheid wat tans binne die multitalige Suid-Afrikaanse taalgemeenskap bestaan.

\section{Bibliografie}

Althusser, L. 1971. Lenin and Philosophy, and Other Essays. Uit Frans vertaal deur Ben Brewster. New York : Monthly Review Press.

Arndt, H. \& Janney, R. 1984. Interpersonal Factors in Intercultural (Mis)understanding. Nagoya Gakuin University Round Table, 10:13-29.

Bosch, Barbara. 1994. 'n Sintakties-semantiese ondersoek na die gebruik van en. Suid-Afrikaanse Tydskrıf vir Taalkunde, Supplement 19:2-35.

Brink, A.P. 1973. Kennis van die aand. Kaapstad: Human \& Rousseau. Brown, P. \& Levinson, S. 1978. Universals in Language Usage: Politeness Phenomena. In: Goody, Esther N. (ed.). Questions and Politeness. Strategies in Social Interaction. Cambridge : Cambridge University Press. p. 56-289.

Calitz, F.C. 1980. Spot, skel en verwante verskynsels in Afrikaans. Stellenbosch : Universiteit van Stellenbosch. (D.Litt.-proefskrif.)

Chick, Keith. 1989. Intercultural Miscommunication as a Source of Friction in the Workplace and in Educational Settings in South Africa. In: Garcia, $O$. \& Otheguy, R. (eds.). English across Cultures. Cultures across English. A Reader in Cross-cultural Communication. Berlyn : Mouton de Gruyter. p. $139-160$.

Cloete, T.T. (red.). 1992. Literêre terme en teorieë. Pretoria : HAUM-Literêr. Coetzee, Ampie. 1990. Letterkunde en krisis. 'n Honderd jaar Afrikaanse letterkunde en Afrikaner-nasionalisme. Pretoria : Taurus.

Conradie, C.J. 1987. Hoe om die kind nie by sy naam te noem nie. In: Van Jaarsveld, G.J. (red.). Wat bedoel jy? Pretoria : Serva-Uitgewers. p. 95108.

9 Kommunikasie vind binne 'n negatiewe raamwerk plaas indien die gespreksgenote ervaar dat daar tussen hulle geen gedeelde belange of kulturele aannames bestaan nie en die gespreksgenote mekaar gevolglik met agterdog begin bejeèn (Janney \& Arndt, 1992:40). 
Barbara Basch

Coulmas, F. (ed.) 1981. Conversational Routine. Explorations in Standardized Communication. Studies and Prepattened Speech. Den Haag : Mouton.

Coupland, N., Coupland, J. \& Giles, H. 1991. Language, Society and the Elderly. Oxford : Basil Blackwell.

Du Plessis, Hans. 1989. Die Afrikaanse taalgemeenskap. In: Botha, T.J.R. (hoofred.). Inleiding tot die Afrikaanse Taalkunde. Tweede, hersiene uitgawe. Pretoria : Academica. p. 468-480.

Ferguson, Charles A. 1981. The Structure and Use of Politeness Formulas. In: Coulmas, F. (ed.). Conversational Routine. Explorations in Standardized Communication Situations and Prepatterned Speech. Den Haag : Mouton Publishers. p. 21-35.

Ferreira, Jeanette. 1986. Voorgeskrewe literatuur aan swart studente: resepsie van die Swerfjare van Poppie Nongena. Tydskrif vir Letterkunde, 24(4):51-57, November.

Fraser, Bnice \& Nolan, William. 1981. The Association Deference with Linguistic Form. International Journal of the Sociology of Language, 27:93109.

Goody, Esther N. (ed.). 1978. Questions and Politeness. Strategies in Social Interaction. Cambridge : Cambridge University Press.

Goosen, Jeanne. 1990. Ons is nie almal so nie. Pretoria : HAUM-Literêr.

Gough, D.H. 1992. Communication in the Dominant Classroom. Ongepubliseerde manuskrip. Rhodes Universiteit.

Grice, H.P. 1975. Logic and Conversation. In: Cole, P. \& Morgan, J.L. (eds.). Syntax and Semantics 3: Speech Acts. New York : Academic Press. p. 41-58.

Held, G. 1992. Politeness in Linguistic Research. In: Watts, Richard J. e.a. (eds.). Trends in Linguistics. Studies and Monographs 59. Politeness in Language. Studies in Its History, Theory and Practice. Berlyn : Mouton de Gruyter. p. 131-153.

House, J. \& Kasper, G. 1981. Politeness Markers in English and German. In: Coulmas, F. (ed.). Conversational Routine. Explorations in Standardized Communication Situations and Prepatterned Speech. Den Haag : Mouton Publishers. p. 157-185.

Janney, Richard W. \& Amdt, Horst. 1992. Intracultural Tact Versus Intercultural Tact. In: Watts, Richard J. e.a. (eds.). Trends in Linguistics. Studies and Monographs 59. Politeness in Language. Studies in Its History, Theory and Practice. Berlyn : Mouton de Gruyter. p. 21-41. 
Jenkinson, A.G. 1987. Aspekte van voornaamwoorde en verwysing in taalhandelinge. In: Van Jaarsveld, G.J. (red.). Wat bedoel jy? Pretoria : Serva-Uitgewers. p. 51-74.

Key, Mary Richie. 1975. Male/Female Language. Metuchen N.J. : The Scarecrow Press.

Lakoff, R. 1975. Language and Woman's Place. London : Harper and Row.

Leech, G.N. 1983. Principles of Pragmatics. London : Longman.

Levinson, S.C. 1983. Pragmatics. Cambridge : Cambridge University Press.

Macherey, Pierre. 1978. A Theory of Literary Production. Transl. Geoffrey

Wall. London : Routledge and Keegan Paul.

Mehrotra, R.R. 1981. Non-kin Forms of Address in Hindi. International Journal of the Sociology of Language, 32:121-137.

Meintjes, W.G. 1994. A Chain of (African) Voices: The Prose Oeuvre of André Brink. Unpublished article.

Odendal, F.F. 1976. Oor die aanspreekvorme in Afrikaans. In: De Klerk, W.J. \& Ponelis, F.A. (reds.). Gedenkbundel H.J.J.M. van der Merwe. Pretoria : Van Schaik.

Ponelis, F.A. 1979. Afrikaanse sintaksis. Pretoria : Van Schaik.

Sell, Roger D. 1992. Literary Texts and Diachronic Aspects of Politeness. In: Watts, Richard J. e.a. (eds.). Trends in Linguistics. Studies and Monographs 59. Politeness in Language. Studies in Its History, Theory and Practice. Berlyn : Mouton de Gruyter. p. 109-129.

Tannen, Deborah. 1992. Je begrijpt me gewoon niet. Hoe vrouwen en mannen met elkaar praten. Vertaal deur Trudy Schermer-Lodema. Amsterdam : Prometheus.

Terblanche, C.J.J. 1987. Gepastheidsvoorwaardes om direktiewe taalhandelinge te onderskei. In: Van Jaarsveld, G.J. (red.). Wat bedoel jy? Pretoria : Serva-Uitgewers. p. 125-138.

Van Heerden, Etienne. 1986. Seur en kleur - oor neosensuur, kwetswoorde en lesers. Tydskrif vir Letterkunde, 24(4):58-65, November.

Van Heerden, Etienne. 1989. 'n Halwe geheue? 'n Standpunt oor die suiwering van tekste. Stilet, 2(1):79-87.

Van Jaarsveld, G.J. 1987. Vraagstellings as taalhandelinge. In: Van Jaarsveld, G.J. (red.). Wat bedoel jy? Pretoria : Serva-Uitgewers. p. 109124.

Watts, Richard J., Ide, Sachiko \& Ehlich, Konrad (eds.). 1992. Trends in Linguistics. Studies and Monographs 59. Politeness in Language. Studies in Its History, Theory and Practice. Berlyn : Mouton de Gruyter. 
Werkhofer, Konrad T. 1992. Traditional and Modern Views: The Social Constitution and the Power of Politeness. In: Watts, Richard J. e.a. (eds.). Trends in Linguistics. Studies and Monographs 59. Politeness in Language. Studies in Its History, Theory and Practice. Berlyn : Mouton de Gruyter. p. 155-199. 
